Disponível em

http://www.anpad.org.br/rac

RAC, Rio de Janeiro, v. 18, Edição Especial, art. 6, pp. 109-133, Dezembro 2014

http://dx.doi.org/10.1590/1982-7849rac20142022

$((c))$ EY-NO

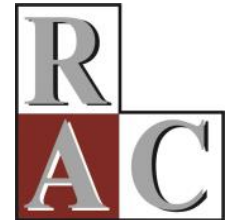

\title{
Two Decades of Research on Strategic Alliances: Analysis of Citations, Co-citations and Themes Researched
}

José Eduardo Storopoli

E-mail: josees@uninove.br

Universidade Nove de Julho - UNINOVE Av. Francisco Matarazzo, 612, Prédio C, 05001-100, São Paulo, SP, Brasil.

Fernando Ribeiro Serra

E-mail: fernandoars@uninove.br

Universidade Nove de Julho - UNINOVE Av. Francisco Matarazzo, 612, Prédio C, 05001-100, São Paulo, SP, Brasil.

Artigo recebido em 05.06.2014. Última versão recebida em 19.10.2014. Aprovado em 20.10.2014. 


\title{
Resumo
}

A pesquisa em alianças estratégicas apresenta longa tradição nos estudos de Administração. As alianças estratégicas têm sido pesquisadas usando múltiplas lentes teóricas, da VBR à Teoria de Agência e à Teoria dos Custos de Transação, e em diversos contextos, da indústria de semicondutores à de aviação civil. Neste estudo, escrutinamos a pesquisa em alianças estratégicas em 31 periódicos de topo em Administração, num período de 20 anos, entre 1993 e 2012. Numa amostra de 866 artigos, realizamos análises de citações e cocitações empregando técnicas de redes sociais, bem como análise fatorial para identificar os principais temas de pesquisa, entender o estoque de conhecimento acumulado e as tendências teóricas. Identificamos algumas mutações da pesquisa ao longo do período - incluindo o foco no desempenho e a ênfase na teoria dos custos de transação e em preocupações de governança para o foco em perspectivas baseadas no aprendizado e transferência de conhecimento, redes sociais e colaboração. Este estudo oferece as fundações sobre as quais pesquisas futuras possam se desenvolver para colmatar lacunas conceituais e empíricas.

Palavras-chave: alianças estratégicas; estudo bibliométrico; análise de cocitações; pesquisa em administração; análise fatorial.

\begin{abstract}
Research on strategic alliances has a long tradition in management studies. Strategic alliances have been investigated using multiple theoretical lenses from RBV to agency and transaction cost, and diverse contexts, from the semiconductor to airline industries. In this study we scrutinize the extant strategic alliance research in thirtyone top-ranked business/management journals, over a twenty-year period, from 1993 to 2012. In a sample of 866 articles we conducted citation and co-citation analyses employing social network techniques and factor analysis to identify research themes and make sense of the stock of accumulated knowledge and theoretical trends. We were able to identify some shifts in research over time, namely from a focus on performance and theoretical emphasis on transaction cost theory and governance concerns, moving to a learning and knowledge transfer approach, social networks and collaboration. This study provides the foundations over which future research may develop to fill conceptual and empirical gaps.
\end{abstract}

Key words: strategic alliances; bibliometric study; co-citation analysis; management research; factor analysis. 


\section{Introduction}

Strategic alliances are interfirm collaborative models that allow firms to create value by sharing an array of possible resources (Anand \& Khanna, 2000), obtain market influence (Koza \& Levin, 1998), learn (Barkema \& Vermeulen, 1998; Vermeulen \& Barkema, 2001), or access novel markets (Harzing, 2002). Gulati (1998) stated that alliances are voluntary agreements that involve the sharing or codevelopment of products, technologies or services. Recognizing the potential positive effects of alliances, including performance effects (Anand \& Khanna, 2000), firms increasingly seem to enter in alliancing agreements (Day, 1995) and seek to construct stable collaborations. While the stories of successful alliances abound, there is also evidence of many failures and decreased performance (Varadarajan \& Cunningham, 1995). The growth in alliances has stimulated a considerable interest in the topic by both scholars and practitioners/managers (Shah \& Swaminathan, 2008).

Research on strategic alliances has grown markedly, especially during the last two decades, but is largely dispersed and fragmented (Moran, Souza, Boaventura, Marinho, \& Fischmann, 2010). For instance, research has taken multiple lenses and contexts, including the process of alliancing (Doz, Olk, \& Ring, 2000; Ring \& Van de Ven, 1994), the transaction costs involved in an alliance (Parkhe, 1993a), or the management costs involved (Harrigan, 1986; Killing, 1983), characteristics of alliances (Borys \& Jemison, 1989), complexity (Killing, 1988), partner selection (Hamel, Doz, \& Prahalad, 1989; Li \& Ferreira, 2008; Ring \& Van de Ven, 1994; Shah \& Swaminathan, 2008), performance and value creation of alliances (Das \& Teng, 1998; Kogut, 1988; Parkhe, 1993a) and longevity (Park \& Ungson, 1997). To make sense of the extant research, which has presumably reached some plateaux of maturity, it is useful to scrutinize the existing research and assess the stock of knowledge generated by the community.

In this paper we used standard bibliometric techniques on articles published in thirty-one international top-ranked management journals, over a period of twenty years, from 1993 to 2012. In a sample of 866 articles collected from Thomson-Reuter's Web of Science (ISI) database, we performed analyses of citation frequencies, co-citation networks and also a factor analysis to derive the sub-fields within strategic alliance research. Given the growing body of research on strategic alliances, it is useful to periodically take a rear view on the stock of accumulated knowledge to make sense of what is already known and from which a novel research agenda may be constructed. Our structural and longitudinal analyses permit summarizing the received wisdom and also understand how research efforts have evolved.

The results identify the most influential works over the period and how their relative influence varied over time. They also reveal the intellectual structure of extant research based on co-citation matrices and social network maps. Moreover, we found how the conceptual basis of the topic has evolved noting that strategic alliance research has been mostly driven by two theoretical lenses, the transaction cost theory and knowledge, learning and capabilities-based approaches. More recently, there has been a gradual growth in social network-based research delving into alliances.

This study complements prior research in understanding the stock of accumulated knowledge on strategic alliance research, thus setting some foundations over which both experienced and novice scholars, as well as doctoral students, may build their research agendas. By cataloging, classifying and analyzing twenty years of publications on strategic alliances we uncovered the major works and theoretical, or conceptual, perspectives taken by scholars, as well as the research shifts that have occurred. Such an extensive bibliometric study also provides validation for what an expert in the field might intuitively infer (Nerur, Rasheed, \& Natarajan, 2008) on how the research on alliances has evolved. It is further worth noting that this study complements existing bibliometric studies on the topic. For instance, Moran, Souza, Boaventura, Marinho e Fischmann (2010) only delved into the authors, works and journals most cited on alliances and employed a rather extensive set of keywords that are likely capturing alternative formats of collaborations between firms beyond alliances. Lin and Cheng (2010) used a less extensive set of journals and did not conduct a longitudinal study. And, Di Guardo and Harrigan (2012) focused only on co-citation analysis to assess the joint literature on alliances and innovation. 
This paper is structured in four sections. First, we briefly review literature on bibliometric studies and techniques involved. Second, we present the methodological details, including the procedures for data collection, sample and method of analysis. The results follow in the third section. The fourth section discusses the results and points out some limitations and future research avenues.

\section{Literature Review}

Broadus (1987) defined bibliometry as the measurement of science, scientists, or scientific activity. Pritchard (1969) proposed that bibliometry is "the application of mathematics and statistical methods to books and other media of communication" (p. 349). Hence, we may sum up that the purpose of bibliometric studies is to catalog, classify and quantify knowledge in a given discipline. In some instances, these bibliometric studies delve into the research trends (Acedo, Barroso, \& Galan, 2006; Furrer, Tomas, \& Goussevskaia, 2008; Shafique, 2013; White \& McCain, 1998), networks of scholars (Shane, 1997) and their productivity, an author (Ferreira, 2011), the themes investigated (Furrer et al., 2008; Schildt, Zahra, \& Silanpää, 2006) or the track record of publications in a journal (Phelan, Ferreira, \& Salvador, 2002; Ramos-Rodríguez \& Ruíz-Navarro, 2004).

Bibliometric studies may use several techniques. The more common techniques are based on citations and co-citations analyses to assess scientific relevance and influence. Citation analysis is based on counting frequencies - the frequency with which a given work is cited by other scholars. The underlying assumption is that scholars cite other works that are relevant to their own research and, hence, that highly cited works have a greater influence on the direction of the research (Culnan, O'Reilly, \& Chatman, 1990), shaping future literature (McCain, 1986, 1990). Co-citation analysis is often used to understand the intellectual structure of a discipline or topic (Leydesdorff, 1987; Ramos-Rodríguez \& Ruíz-Navarro, 2004; Subramanyam, 1983). Co-citation is a form of document coupling that measures how frequently a pair of documents is cited together and the clusters of co-cited papers permits identifying the structure of science (Small, 1973) in a discipline or topic. That is, because as the same pairs of works (scientific articles or other source documents) are co-cited by many scholars, clusters start to emerge (Small \& Garfield, 1993). The assumption is that the papers in these clusters share content commonalities.

Management scholars are not strangers to bibliometrics research (McCain, 1991). For instance, Acedo, Barroso, and Galan's (2006) bibliometric study examined the dissemination and main trends of the RBV. Ramos-Rodríguez and Ruíz-Navarro (2004) conducted a bibliometric study in a single journal, the Strategic Management Journal, to identify the works with the greatest impact on strategic management research and analyze the changes in the intellectual structure of the discipline over time. Nerur, Rasheed and Natarajan (2008) traced the evolution of the intellectual structure of the field of strategic management. Shafique (2013) studied innovation as a field of research among four major social science disciplines (economics, sociology, psychology and management) through citation and cocitation matrices. In international Business, Ferreira (2011) examined the impact of a scholar, Sumantra Ghoshal, on the research conducted in the discipline. In entrepreneurship, Schildt, Zahra and Silanpää (2006) identified the communities of scholars through co-citations. In information science, White and McCain (1998) conducted an author co-citation analysis to visualize the discipline.

\section{Method}

\section{Data collection procedures}

This study focuses exclusively on articles published in top business/management peer-reviewed journals. To collect the sample, we started by selecting thirty-one top-ranked management journals and 
defining the time span for the study: 1993 to 2012 (see Table 1). The journal selection criteria rested on journal impact factors complemented with Ann-Will Harzing's (2014) journal quality list. We further considered journals more likely to publish papers on strategic alliances, which encompassed journals with a broad management emphasis, journals on strategy and international business. Moreover, we included journals with a more practitioner orientation, such as Harvard Business Review and Sloan Management Review. While there is wide variation in the selection criteria in prior bibliometric studies, several authors have selected just one journal - for instance, Ramos-Rodríguez and Ruíz-Navarro (2004) and Nerur et al. (2008) used only the Strategic Management Journal to study the changes that have taken place in the intellectual structure of the discipline of strategic management. Other scholars used multiple journals. For instance, Acedo et al. (2006) selected several journals using impact factor, and Shafique (2013) resorted to the top 20 ISI-listed journals in each of the four disciplines: economics, sociology, psychology and management. Using a wider sample of articles, collected from multiple journals, has the advantage of broader coverage but also of avoiding potential bias or editorial shifts that a study conducted in a single journal could entail.

Table 1

Journals Selection and Sample

\begin{tabular}{|c|c|c|c|c|c|c|}
\hline Journals & $\begin{array}{l}\text { Founding year } \\
\text { (First year } \\
\text { available in } \\
\text { ISI) }\end{array}$ & $\begin{array}{c}2012 \\
\text { Impact } \\
\text { factor (a) }\end{array}$ & $\begin{array}{l}5 \text {-year } \\
\text { impact } \\
\text { factor }\end{array}$ & $\begin{array}{l}\text { Papers on } \\
\text { strategic } \\
\text { alliances }\end{array}$ & $\begin{array}{l}\text { Number of } \\
\text { papers } \\
\text { published: } \\
1993-2012\end{array}$ & $\%(c)$ \\
\hline Strategic Management Journal & $1980(1980)$ & 3.367 & 6.393 & 130 & 1,162 & 11.2 \\
\hline Technovation & $1981(1981)$ & 3.177 & 3.449 & 65 & 856 & 7.6 \\
\hline Journal of Business Research & $1973(1973)$ & 1.484 & 2.203 & 64 & 2,376 & 2.7 \\
\hline Research Policy & 1972 (1974) & 2.850 & 4.387 & 61 & 1,682 & 3.6 \\
\hline Organization Science & $1990(1990)$ & 3.351 & 5.506 & 61 & 1,044 & 5.8 \\
\hline Journal of Management Studies & 1964 (1966) & 3.799 & 4.744 & 61 & 1,055 & 5.8 \\
\hline Long Range Planning & $1968(1968)$ & 3.667 & 2.885 & 57 & 865 & 6.6 \\
\hline $\begin{array}{l}\text { J. of International Business } \\
\text { Studies }\end{array}$ & 1970 (1976) & 3.062 & 5.183 & 49 & 965 & 5.1 \\
\hline $\begin{array}{l}\text { Academy of Management } \\
\text { Journal }\end{array}$ & $1958(1958)$ & 5.906 & 10.031 & 42 & 1,213 & 3.5 \\
\hline Journal of World Business & 1966 (1997) & 2.617 & 3.330 & 33 & 524 & 6.3 \\
\hline Journal of Management & $1975(1983)$ & 6.704 & 7.754 & 26 & 853 & 3.1 \\
\hline International Business Review & $1992(2005)$ & 1.849 & 2.330 & 24 & 377 & 6.4 \\
\hline Management Science & 1954 (1954) & 1.733 & 3.057 & 21 & 2,581 & 0.8 \\
\hline Organization Studies & $1980(1981)$ & 2.190 & 3.229 & 19 & 1,023 & 1.9 \\
\hline British Journal of Management & $1990(2000)$ & 2.044 & 2.391 & 18 & 485 & 3.7 \\
\hline $\begin{array}{l}\text { Journal of International } \\
\text { Management }\end{array}$ & $1995(2007)$ & 2.200 & 2.781 & 17 & 163 & 10.0 \\
\hline $\begin{array}{l}\text { Academy of Management } \\
\text { Review }\end{array}$ & 1976 (1983)d & 7.895 & 11.578 & 17 & 703 & 2.4 \\
\hline California Management Review & $1958(1958)$ & 1.667 & 2.559 & 15 & 555 & 2.7 \\
\hline
\end{tabular}


Table 1 (continued)

\begin{tabular}{|c|c|c|c|c|c|c|}
\hline Journals & $\begin{array}{l}\text { Founding year } \\
\text { (First year } \\
\text { available in } \\
\text { ISI) }\end{array}$ & $\begin{array}{c}2012 \\
\text { Impact } \\
\text { factor (a) }\end{array}$ & $\begin{array}{c}\text { 5-year } \\
\text { impact } \\
\text { factor }\end{array}$ & $\begin{array}{c}\text { Papers on } \\
\text { strategic } \\
\text { alliances }\end{array}$ & $\begin{array}{l}\text { Number of } \\
\text { papers } \\
\text { published: } \\
\text { 1993-2012 }\end{array}$ & $\%(c)$ \\
\hline Harvard Business Review & $1956(1956)$ & 1.519 & 1.998 & 12 & 1,821 & 0.7 \\
\hline $\begin{array}{l}\text { Asia Pacific Journal of } \\
\text { Management }\end{array}$ & $1984(2008)$ & 4.089 & n.a. & 11 & 185 & 6.0 \\
\hline $\begin{array}{l}\text { Administrative Science } \\
\text { Quarterly }\end{array}$ & $1956(1956)$ & 4.182 & 7.693 & 10 & 405 & 2.5 \\
\hline $\begin{array}{l}\text { Academy of Management } \\
\text { Executive }^{\mathrm{a}}\end{array}$ & $1990(2000)$ & n.a & n.a & 10 & 218 & 4.6 \\
\hline Strategic Organization & $2003(2007)$ & 1.769 & 3.630 & 7 & 81 & 8.6 \\
\hline European Management Journal & $1982(2009)$ & 0.566 & n.a & 7 & 160 & 4.4 \\
\hline Sloan Management Review & $1959(1970)$ & 1.413 & 1.704 & 6 & 241 & 2.5 \\
\hline MIS Quarterly & $1977(1981)$ & 4.659 & 7.474 & 6 & 594 & 1.0 \\
\hline $\begin{array}{l}\text { Omega -Int. Jrl of Management } \\
\text { Science }\end{array}$ & 1973 (1974) & 3.024 & 3.474 & 5 & 1,190 & 0.4 \\
\hline Business History & $1958(1958)$ & 0.474 & 0.638 & 5 & 584 & 0.9 \\
\hline $\begin{array}{l}\text { Academy of Management } \\
\text { Perspectives }\end{array}$ & 1987 (2006) & 3.174 & 3.318 & 4 & 205 & 1.9 \\
\hline $\begin{array}{l}\text { Int. Journal of Management } \\
\text { Reviews }\end{array}$ & $1999(2001)$ & 3.333 & 4.981 & 2 & 194 & 1.0 \\
\hline Organization & 1994 (1995) & 2.356 & 2.593 & 1 & 653 & 0.1 \\
\hline Total & & & & 866 & 25.397 & \\
\hline
\end{tabular}

Note. Founding years collected from the journals' webpages. (a) Data collected from the 2012 JCR Social Sciences Edition. (b) Number of articles, review articles and research notes published in the journal in the period of 1993 to 2012. (c) Sample as $\%$ of articles published.

a Journal discontinued in 2005.

Using ISI web of knowledge, and restricting the search to the journals and the time frame defined, we conducted a keyword search in the option topic for articles using the following parameters: strategic* alliance*. The asterisk, when applied to a keyword search, permits us to capture possible variations of the wording. We did not include an explicit search for joint ventures, albeit many papers will refer to JVs as a form of alliances and some authors refer to JVs as equity alliances. The software searches every document in the title, abstract and keywords. While apparently narrow, this search assures a return comprising only articles that actually deal with alliances, rather than, for example, briefly referring to alliances. In any instance, each article was examined to guarantee it actually dealt with alliances as intended.

\section{Sample}

Employing the procedures explained above we identified 866 articles that comprise our final sample. Figure 1 shows the evolution of publications on strategic alliances over the period 1993 to 2012, a twenty-year period. We observe a rising trend, with more than 70 papers published in 2012, from a meager 15 in 1993. Examining Table 1, we observe how the sample is distributed among the journals selected. The journals that have published more articles on alliances were the Strategic Management Journal (almost 10\% of the papers published dealt with strategic alliances), Technovation, Journal of Business Research, Research Policy, Organization Science, Journal of Management Studies, Long 
Range Planning, Journal of International Business Studies and Academy of Management Journal. It is worth noting that there was also an increase in the overall number of papers published over time, namely as new journals emerged. In fact, four journals were founded after 1993.

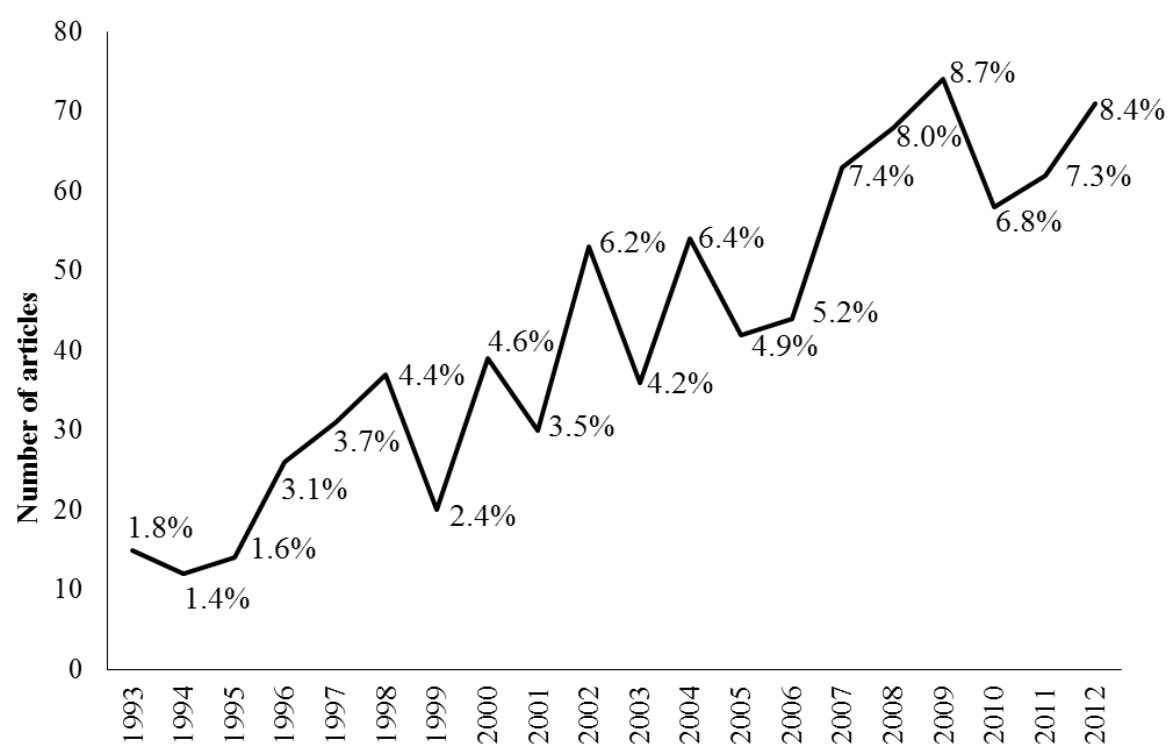

Figure 1. Evolution of Publications on Strategic Alliances.

Source: Data retrieved from Web of Science. (n.d.). Faça login para acessar o Web of Science. Retrieved from http://apps.webofknowledge.com/WOS_GeneralSearch_input.do?product=WOS\&SID=Q2VSsC8ChkihDbZkvFR\&search_ mode $=$ GeneralSearch

\section{Procedures of analyses}

The study comprises analyses of citations, co-citations and factor analysis, for both the entire period and in 5-year periods to enable a longitudinal outlook. First, we conducted citation analysis. Examining citations is relevant not only because we may identify who the main scholars and works driving the intellectual development of the research topic were, but also because it is an initial signal of the topics and theories delved into. The citation analysis involved collecting all references from the 866 articles in the sample, adjusting, classifying, ranking and summarizing the data. We report only the forty most-influential, or highly-cited, articles as determined by the citation counts (see Table 2). Moreover, we also identify the most influential works longitudinally, in 5-year periods.

The second procedure involved identifying the main topics or theories in strategic alliance research and we conducted a factor analysis. Using the co-citation matrices, we performed factor analyses with varimax rotation (see Acedo et al., 2006; Lin \& Cheng, 2010). Albeit we considered alternatives, such as the oblimin rotation, an orthogonal rotation, such as varimax, returns more easily interpretable results (Fabrigar, Wegener, MacCallum, \& Strahan, 1999). In a factor analysis, the articles that are conceptually proximate, or that deal with a certain theme, tend to load on the same factor. The loads indicate how well the article belongs to the factor. Then, we may interpret the factor and infer the theme of the factor by examining the articles that compose it (Lin \& Cheng, 2010). Following Shafique (2013), we considered values greater than 0.4 as a prerequisite for the variable to be loaded in a factor. Each factor thus represents a sub-theme of research on strategic alliances as derived from the co-citations in the sample.

The third procedure entailed a co-citation analysis. Co-citations have been used to infer the intellectual structure of a discipline and how scholars and theories are inter-connected (Lin \& Cheng, 2010; McCain, 1986; Ramos-Rodríguez \& Ruíz-Navarro, 2004). We created a co-citation matrix using only the top 30 most-cited papers, by counting the frequency with which a given pair of works was jointly used by other authors. We conducted this analysis for the entire time span and for each 5-year period (the latter not shown here). Using Ucinet we mapped the social networks, permitting a visual 
identification of the relative strength of the ties binding works. In the two dimensional figure, each node is a work, connected to other works by lines of different lengths and thickness that represent the frequency of co-citation between a given pair of works. Moreover, the works are positioned in a space according to their relative importance to the overall network.

\section{Results}

\section{Citation analyses}

Table 2 displays the most-cited works, both during the entire period (1993 to 2012) and each 5year period. The columns reveal both the absolute frequency and a relative measure of how often each work is cited in the period. For instance, Hamel (1991) was cited 251 times over the entire time span, or by about $30 \%$ of the 866 articles in the sample, and the citations to this work have been increasing over time. The list is organized by the last column, referring to the entire period.

Table 2

\section{Raw and Relative Citation Frequency Per Period}

\begin{tabular}{|c|c|c|c|c|c|c|c|c|c|c|}
\hline \multirow[t]{2}{*}{ Document } & \multicolumn{2}{|c|}{$\begin{array}{c}\text { 1993-1997 } \\
(n=98)\end{array}$} & \multicolumn{2}{|c|}{$\begin{array}{c}\text { 1998-2002 } \\
(n=179)\end{array}$} & \multicolumn{2}{|c|}{$\begin{array}{c}\mathbf{2 0 0 3 - 2 0 0 7} \\
(n=241)\end{array}$} & \multicolumn{2}{|c|}{$\begin{array}{l}\text { 2008-2012 }(n \\
\quad=348)\end{array}$} & \multicolumn{2}{|c|}{$\begin{array}{c}\text { 1993-2012 } \\
(n=866)\end{array}$} \\
\hline & $\mathrm{n}$ & $\%$ & $\mathrm{n}$ & $\%$ & $\mathrm{n}$ & $\%$ & $\mathrm{n}$ & $\%$ & $\mathrm{n}$ & $\%$ \\
\hline Hamel (1991) & 28 & 28.6 & 70 & 39.1 & 71 & 29.7 & 82 & 24.6 & 251 & 29.0 \\
\hline Cohen and Levinthal (1990) & 10 & 10.2 & 36 & 20.1 & 67 & 28.0 & 111 & 33.3 & 224 & 25.9 \\
\hline Dyer and Singh (1998) & - & - & 30 & 16.8 & 75 & 31.4 & 96 & 28.8 & 201 & 23.2 \\
\hline Gulati (1995a) & 11 & 11.2 & 46 & 25.7 & 57 & 23.8 & 83 & 24.9 & 197 & 22.8 \\
\hline Kogut (1988) & 28 & 28.6 & 54 & 30.2 & 50 & 20.9 & 55 & 16.5 & 187 & 21.6 \\
\hline $\begin{array}{l}\text { Powell, Koput and Smith-Doerr } \\
\text { (1996) }\end{array}$ & 2 & 2.0 & 32 & 17.9 & 52 & 21.8 & 86 & 25.8 & 172 & 19.9 \\
\hline Williamson (1985) & 19 & 19.4 & 39 & 21.8 & 49 & 20.5 & 60 & 18.0 & 167 & 19.3 \\
\hline $\begin{array}{l}\text { Mowery, Oxley and Silverman } \\
\text { (1996) }\end{array}$ & 0 & 0.0 & 30 & 16.8 & 55 & 23.0 & 76 & 22.8 & 161 & 18.6 \\
\hline Parkhe (1993a) & 14 & 14.3 & 37 & 20.7 & 43 & 18.0 & 63 & 18.9 & 157 & 18.1 \\
\hline Doz (1996) & 1 & 1.0 & 43 & 24.0 & 57 & 23.8 & 51 & 15.3 & 152 & 17.6 \\
\hline Gulati (1998) & - & - & 28 & 15.6 & 56 & 23.4 & 60 & 18.0 & 144 & 16.6 \\
\hline Barney (1991) & 7 & 7.1 & 30 & 16.8 & 39 & 16.3 & 63 & 18.9 & 139 & 16.1 \\
\hline Lane and Lubatkin (1998) & - & - & 18 & 10.1 & 44 & 18.4 & 76 & 22.8 & 138 & 16.0 \\
\hline Hagedoorn (1993) & 22 & 22.4 & 35 & 19.6 & 38 & 15.9 & 42 & 12.6 & 137 & 15.9 \\
\hline Nelson and Winter (1982) & 8 & 8.2 & 23 & 12.8 & 43 & 18.0 & 58 & 17.4 & 132 & 14.9 \\
\hline Ring and Van de Ven (1994) & 11 & 11.2 & 30 & 16.8 & 39 & 16.3 & 48 & 14.4 & 128 & 14.8 \\
\hline Kogut and Zander (1992) & 5 & 5.1 & 17 & 9.5 & 38 & 15.9 & 61 & 18.3 & 121 & 14.3 \\
\hline Kale, Singh and Perlmutter (2000) & - & - & 7 & 3.9 & 36 & 15.1 & 74 & 22.2 & 117 & 13.8 \\
\hline
\end{tabular}


Table 2 (continued)

\begin{tabular}{|c|c|c|c|c|c|c|c|c|c|c|}
\hline \multirow[t]{2}{*}{ Document } & \multicolumn{2}{|c|}{$\begin{array}{c}\text { 1993-1997 } \\
(n=98)\end{array}$} & \multicolumn{2}{|c|}{$\begin{array}{c}\text { 1998-2002 } \\
(n=179)\end{array}$} & \multicolumn{2}{|c|}{$\begin{array}{c}2003-2007 \\
(n=241)\end{array}$} & \multicolumn{2}{|c|}{$\begin{array}{l}\text { 2008-2012 }(n \\
\quad=348)\end{array}$} & \multicolumn{2}{|c|}{$\begin{array}{c}\text { 1993-2012 } \\
(n=866)\end{array}$} \\
\hline & $\mathrm{n}$ & $\%$ & $\mathrm{n}$ & $\%$ & $\mathrm{n}$ & $\%$ & $\mathrm{n}$ & $\%$ & $\mathrm{n}$ & $\%$ \\
\hline Williamson (1975) & 18 & 18.4 & 15 & 8.4 & 32 & 13.4 & 51 & 15.3 & 116 & 13.7 \\
\hline Khanna, Gulati and Nohria (1998) & - & - & 21 & 11.7 & 40 & 16.7 & 54 & 16.2 & 115 & 13.5 \\
\hline Granovetter (1985) & 10 & 10.2 & 24 & 13.4 & 28 & 11.7 & 53 & 15.9 & 115 & 13.5 \\
\hline Uzzi (1997) & 1 & 1.0 & 15 & 8.4 & 26 & 10.9 & 68 & 20.4 & 110 & 13.0 \\
\hline Gulati (1995b) & 4 & 4.1 & 19 & 10.6 & 32 & 13.4 & 53 & 15.9 & 108 & 12.7 \\
\hline Hamel and Prahalad (1989) & 23 & 23.5 & 31 & 17.3 & 27 & 11.3 & 27 & 8.1 & 108 & 12.7 \\
\hline Burt (1992) & 1 & 1.0 & 23 & 12.8 & 26 & 10.9 & 55 & 16.5 & 105 & 12.4 \\
\hline Anand and Khanna (2000) & - & - & 8 & 4.5 & 42 & 17.6 & 55 & 16.5 & 105 & 12.4 \\
\hline Pfeffer and Salancik (1978) & 14 & 14.3 & 29 & 16.2 & 27 & 11.3 & 33 & 9.9 & 103 & 12.1 \\
\hline Hennart (1988) & 14 & 14.3 & 30 & 16.8 & 30 & 12.6 & 28 & 8.4 & 102 & 12.0 \\
\hline $\begin{array}{l}\text { Eisenhardt and Schoonhoven } \\
\text { (1996) }\end{array}$ & 3 & 3.1 & 25 & 14.0 & 32 & 13.4 & 41 & 12.3 & 101 & 11.9 \\
\hline Williamson (1991) & 13 & 13.3 & 26 & 14.5 & 33 & 13.8 & 28 & 8.4 & 100 & 11.8 \\
\hline Gulati and Singh (1998) & - & - & 9 & 5.0 & 30 & 12.6 & 59 & 17.7 & 98 & 11.5 \\
\hline Inkpen and Beamish (1997) & - & - & 34 & 19.0 & 29 & 12.1 & 33 & 9.9 & 96 & 11.3 \\
\hline March (1991) & 4 & 4.1 & 10 & 5.6 & 26 & 10.9 & 54 & 16.2 & 94 & 11.1 \\
\hline Parkhe (1991) & 17 & 17.3 & 34 & 19.0 & 21 & 8.8 & 20 & 6.0 & 92 & 10.8 \\
\hline Koza and Lewin (1998) & - & - & 17 & 9.5 & 34 & 14.2 & 37 & 11.1 & 88 & 10.4 \\
\hline Teece, Pisano and Shuen (1997) & - & - & 14 & 7.8 & 23 & 9.6 & 51 & 15.3 & 88 & 10.4 \\
\hline Ring and Van de Ven (1992) & 10 & 10.2 & 28 & 15.6 & 25 & 10.5 & 21 & 6.3 & 84 & 9.9 \\
\hline Ariño and Torre (1998) & - & - & 21 & 11.7 & 27 & 11.3 & 33 & 9.9 & 81 & 9.5 \\
\hline Kale, Dyer and Singh (2002) & - & - & - & - & 26 & 10.9 & 55 & 16.5 & 81 & 9.5 \\
\hline $\begin{array}{l}\text { Baum, Calabrese and Silverman } \\
(2000)\end{array}$ & - & - & 8 & 4.5 & 21 & 8.8 & 52 & 15.6 & 81 & 9.5 \\
\hline
\end{tabular}

Note. Source: Authors' computations.

$n=$ number of articles in the sample in each period.

The most cited, and thus most influential, articles were published prior to the 2000's, and the majority were published between 1986 and 1998. Examining the citation data is also interesting in order to identify which works have seen a relative decrease in citations. The shaded cells highlight some more notable shifts. Table 3 depicts only the top most-cited per period. Hamel (1991) is the only work that appeared in the top 5 in all periods. While Cohen and Levinthal's (1990) work increases in influence, Williamson's work lost some impact, which may be evidence for a decreased emphasis on transaction costs. Moreover, there seems to be a jolt between the period 1998-2002 and 2003-2007, denoting a conceptual shift - further examined below. 
Table 3

Top-Cited Works Per Period

\begin{tabular}{|c|c|c|c|c|c|c|c|}
\hline 1993-1997 & & 1998-2002 & & 2003-2007 & & 2008-2012 & \\
\hline Hamel (1991) & 28 & Hamel (1991) & 70 & $\begin{array}{l}\text { Dyer and Singh } \\
\text { (1998) }\end{array}$ & 75 & $\begin{array}{l}\text { Cohen and Levinthal } \\
\text { (1990) }\end{array}$ & 111 \\
\hline Kogut (1988) & 28 & Kogut (1988) & 54 & Hamel (1991) & 71 & $\begin{array}{l}\text { Dyer and Singh } \\
\text { (1998) }\end{array}$ & 96 \\
\hline $\begin{array}{l}\text { Hamel and Prahalad } \\
\text { (1989) }\end{array}$ & 23 & Gulati (1995a) & 46 & $\begin{array}{l}\text { Cohen and Levinthal } \\
\text { (1990) }\end{array}$ & 67 & Powell et al. (1996) & 86 \\
\hline Killing (1983) & 23 & Doz (1996) & 43 & Gulati (1995a) & 57 & Gulati (1995a) & 83 \\
\hline Hagedoorn (1993) & 22 & Williamson (1985) & 39 & Doz (1996) & 57 & Hamel (1991) & 82 \\
\hline Williamson (1985) & 19 & Parkhe (1993a) & 37 & Gulati (1998) & 56 & Mowery et al. (1996) & 76 \\
\hline Harrigan (1985) & 19 & $\begin{array}{l}\text { Cohen and Levinthal } \\
\text { (1990) }\end{array}$ & 36 & Mowery et al. (1996) & 55 & $\begin{array}{l}\text { Lane and Lubatkin } \\
\text { (1998) }\end{array}$ & 76 \\
\hline Williamson (1975) & 18 & Hagedoorn (1993) & 35 & Powell et al. (1996) & 52 & Kale et al. (2000) & 74 \\
\hline Parkhe (1991) & 17 & $\begin{array}{l}\text { Inkpen and Beamish } \\
\text { (1997) }\end{array}$ & 34 & Kogut (1988) & 50 & Uzzi (1997) & 68 \\
\hline
\end{tabular}

Note. Values are citation frequencies. Source: Computations by the authors.

\section{Factor analysis}

Factor analysis may be conducted using the co-citation matrix to derive sub-fields (Lin \& Cheng, 2010). Each factor identified constitutes a subfield that reveals the intellectual topic or theory, as defined by the content of the articles that load on that factor (Nerur et al., 2008). The factor loadings show how well a given article truly belongs to a factor. The factors that have greater impact will account for a larger number of works, and variance explained. It is worth noticing that each work was selected to the factor in which it had a higher load, albeit it is conceptually possible that a specific work may contribute to more than one research stream. The load is an indication of the extent to which the work belongs to that factor. We conducted the analysis for the entire period and for each of the four sub-periods identified previously. The works that appear in more than one period are likely to be hold greater impact on strategic alliance research.

The first factor analysis pertained to the entire time frame (1993 to 2012) and used the co-citation matrix of the 40 most-cited works. Table 4 summarizes the results arranged by factor (loadings in parenthesis) and shows the extraction of four factors, jointly explaining $65 \%$ of the variance. Factor $1-$ which we termed Governance and transaction costs - comprises 16 works. These works focus on transaction costs, namely those emerging from opportunism and firms' self-interest behaviors (Hennart, 1988; Williamson, 1975, 1985, 1991) that are involved when firms decide to form alliances. Parkhe (1993a) advances governance forms to minimize the potential costs, combining a game-theory perspective, while Ring and Van de Ven (1994) treat opportunism. Hence, several of these works deal with conditions pertaining to how to make alliances successful, how they emerge and evolve, their scope, and how partners are selected (Khanna, Gulati, \& Nohria, 1998; Parkhe, 1991). 
Table 4

Summary of Factor Analysis: 1993-2012

\begin{tabular}{|c|c|c|c|}
\hline $\begin{array}{l}\text { Governance and transaction } \\
\text { costs }\end{array}$ & $\begin{array}{l}\text { Learning, knowledge and } \\
\text { capabilities }\end{array}$ & Social networks & $\begin{array}{l}\text { Alliance formation } \\
\text { and coordination }\end{array}$ \\
\hline Hennart $(1988)-0.84$ & March $(1991)-0.85$ & Burt (1992) -0.75 & Gulati (1998) - 0.87 \\
\hline Inkpen and Beamish (1997) - 0.84 & \multirow{2}{*}{$\begin{array}{l}\text { Kogut and Zander (1992) - } \\
0.82\end{array}$} & \multirow{5}{*}{$\begin{array}{l}\text { Baum et al. (2000) } \\
-0.71 \\
\text { Uzzi (1997) - 0.67 } \\
\text { Granovetter }(1985) \\
-0.67\end{array}$} & \multirow{2}{*}{$\begin{array}{l}\text { Gulati and Singh } \\
(1998)-0.86\end{array}$} \\
\hline Ring and Van de Ven (1992) - 0.83 & & & \\
\hline Parkhe (1991) - 0,82 & \multirow{2}{*}{$\begin{array}{l}\text { Lane and Lubatkin (1998)- } \\
0.81\end{array}$} & & \multirow{6}{*}{$\begin{array}{l}\text { Gulati (1995a) - } \\
0.84 \\
\text { Gulati (1995b) - } \\
0.83\end{array}$} \\
\hline Ring and Van de Ven (1994) - 0.82 & & & \\
\hline Ariño and Torre $(1998)-0.81$ & Mowery et al. (1996) - 0.77 & & \\
\hline Parkhe $(1993 a)-0.78$ & Nelson and Winter (1982) - & \multirow{14}{*}{$\begin{array}{l}\text { Eisenhardt and } \\
\text { Schoonhoven } \\
(1996)-0.65\end{array}$} & \\
\hline Williamson (1991) - 076 & & & \\
\hline Williamson (1991) - 0.76 & Kale et al. (2000) - 0.75 & & \\
\hline $\operatorname{Doz}(1996)-0.70$ & Teece et al. (1997) - 0.72 & & \\
\hline Williamson $(1985)-0.69$ & Barney (1991) - 0.66 & & \\
\hline Williamson $(1975)-0.68$ & Cohen and Levinthal (1990) - & & \\
\hline Pfeffer and Salancik (1978) - 0.65 & 0.61 & & \\
\hline Hamel and Prahalad (1989) - 0.65 & Powell et al. (1996) - 0.60 & & \\
\hline $\begin{array}{l}\text { Khanna, Gulati and Nohria (1998) } \\
-0.61\end{array}$ & $\begin{array}{l}\text { Koza and Lewin (1998) - } \\
0.56\end{array}$ & & \\
\hline Kogut $(1988)-0.60$ & Anand and Khanna (2000) - & & \\
\hline \multirow[t]{4}{*}{ Hamel $(1991)-0.45$} & 0.55 & & \\
\hline & Kale et al. (2002) - 0.53 & & \\
\hline & Hagedoorn (1993) - 0.51 & & \\
\hline & Dyer and Singh $(1998)-0.49$ & & \\
\hline
\end{tabular}

Note. Values are the loadings in the factor. Source: Authors computations.

The second factor - Learning, knowledge and capabilities - comprises 15 works. This factor includes works such as March (1991), Kogut and Zander (1992), Lane and Lubatkin (1998), Mowery et al. (1996), Nelson and Winter (1982), Kale et al. (2000), Teece et al. (1997), Barney (1991) and Cohen and Levinthal (1990) discussing how firms may learn from partners and the challenges involved. Specifically, we observe a focus on firms' absorptive capacity, and how knowledge may be transferred in an alliance, taking on a Resource-based view approach. For instance, Mowery et al. (1996) noted that equity-based partnerships are better suited for knowledge transfer. March (1991) dealt with exploration and exploitation which, when applied to alliances, may entail understanding the strategic purpose of the alliance. Lane and Lubatkin (1998) treated interfirm differences in absorptive capacity (Cohen \& Levinthal, 1990) noting that the similarity of knowledge held by partners, and other organizational factors are positively related to interorganizational learning.

The third factor - Social networks - includes works focusing on multiple facets of the social aspect, or interactions, of alliances. Baum et al. (2000) argue that firms improve the chances of success by engaging in alliances and constructing effective networks. Uzzi (1997) complements Granovetter's (1985) on social embeddedness noting that embedded ties provide trust, information and joint problemsolving. Eisenhardt and Schoonhoven (1996) reveal the importance of ties for entrepreneurial firms in accessing a variety of resources. Specifically, they argue that transaction-cost based explanations fail to consider the strategic and social motivations underlying why firms form alliances.

The fourth factor includes only four works by Ranjay Gulati on alliance formation and coordination of the relationships between partners both in a dyadic situation and in a network of repeated ties. Gulati (1995a) specifically delves into how the interfirm trust that emerges in repeated alliances decreases coordination costs. 
We also conducted a factor analysis for each 5 -year period (Table 5 summarizes the factors and the works loading on each factor per period). We only extracted factors that had eigenvalues greater than 1 and all works had loadings greater than 0.4 (see Nerur et al., 2008). The factors are reported in tables 4 and 5, exactly as the statistical output, and they were not manipulated. Albeit we identify many commonalities concerning the use of three main conceptual approaches - Transaction Costs Theory, Knowledge and Learning-based view and Social networks - across the periods, there are notable shifts over time that are worth noting. For instance, there was an emphasis on Performance and competitive strategy effects and on International joint ventures during the period 1993 to 1997, and on aspects of interfirm coordination and alliance formation in three periods (1993-1997, 2003-2007, 2008-2012) albeit with slight differences among the periods. Joint ventures were a recurring theme in the first two periods. Although conceptually different, alliances and joint ventures are often contrasted or used to distinguish between equity-based and non-equity based agreements.

Table 5

\section{Summary of the Factor Analyses Per Period}

\begin{tabular}{|c|c|c|}
\hline \multirow{3}{*}{ के } & $\begin{array}{l}\text { Performance and } \\
\text { competitive strategy }\end{array}$ & $\begin{array}{l}\text { Porter (1990) - 0.85; Harrigan (1985) - 0.72; Harrigan (1986) - 0.72; Hamel } \\
\text { and Prahalad (1989) - 0.69; Killing (1983) - 0.59; Geringer (1989) - 0.58; } \\
\text { Reich and Mankin (1986) - 0.57; Hennart (1988) - 0.56; Ring and Van de } \\
\text { Ven (1994) - 0.50; Pfeffer and Salancik (1978) - 0.49; Hamel (1991) - 0.48; } \\
\text { Contractor and Lorange (1988) - 0.46; Harrigan (1988) - } 0.43\end{array}$ \\
\hline & International JVs & $\begin{array}{l}\text { Kogut (1988) - 0.66; Parkhe (1991) - 0.66; Hladik (1985) - 0.65; Parkhe } \\
\text { (1993a) - 0.63; Geringer (1991) - 0.62; Kogut (1989) - 0.61; Parkhe (1993b) } \\
\text { - 0.59; Buckley and Casson (1988) - 0.58; Porter (1986) - 0.53; Osborn and } \\
\text { Baughn (1990) - 0.48 }\end{array}$ \\
\hline & $\begin{array}{l}\text { Governance and } \\
\text { transaction costs }\end{array}$ & $\begin{array}{l}\text { Porter (1985) - 0.79; Axelrod (1984) - 0.72; Powell (1990) - 0.72; } \\
\text { Williamson (1991) - 0.70; Williamson (1975) - 0.63; Porter (1980) - 0.62; } \\
\text { Williamson (1985) - 0.59; Borys e Jemison (1989) - } 0.56\end{array}$ \\
\hline \multirow{4}{*}{ 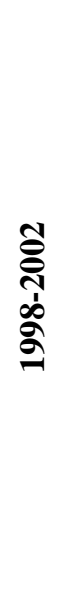 } & Transaction costs & $\begin{array}{l}\text { Yan and Gray (1994) - 0.82; Killing }(1983)-0.79 ; \text { Parkhe }(1991)-0.79 ; \\
\text { Hennart }(1988)-0.77 \text {; Ring and Van de Ven }(1994)-0.77 \text {; Inkpen and } \\
\text { Beamish }(1997)-0.77 \text {; Parkhe }(1993 a)-0.74 ; \text { Hamel and Prahalad }(1989) \\
\text { - 0.64; Borys and Jemison }(1989)-0.63 ; \text { Doz }(1996)-0.61 \text {; Hamel }(1991) \\
\text { - 0.56; Harrigan }(1985)-0.51 ; \text { Williamson }(1985)-0.46\end{array}$ \\
\hline & $\begin{array}{l}\text { Learning, networks and } \\
\text { access resources }\end{array}$ & $\begin{array}{l}\text { Granovetter (1985) - 0.80; Burt (1992) - 0.78; Hagedoorn (1993) - 0.73; } \\
\text { Dyer and Singh (1998) - 0.72; Powell et al. (1996) - 0.71; Eisenhardt and } \\
\text { Schoonhoven (1996) - 0.71; Williamson (1991) - 0.65; Nelson and Winter } \\
(1982) \text { - 0.63; Pfeffer and Salancik (1978) - 0.58; Cohen and Levinthal } \\
(1990) \text { - 0.54; Mowery et al. (1996) - 0.50; Barney (1991) - 0.46 }\end{array}$ \\
\hline & $\begin{array}{l}\text { JVs: structure and } \\
\text { reciprocity }\end{array}$ & $\begin{array}{l}\text { Kogut (1988) - 0.81; Kogut (1989) - 0.64; Ring and Van de Ven (1992) - } \\
0.53\end{array}$ \\
\hline & Interfirm coordination & Gulati (1995a) - 0.82; Gulati (1998) - 0.75 \\
\hline
\end{tabular}

Continues 
Table 5 (continued)

\begin{tabular}{|c|c|c|}
\hline \multirow{4}{*}{ ڤ్రి } & $\begin{array}{l}\text { Learning and } \\
\text { collaboration }\end{array}$ & $\begin{array}{l}\text { Nelson and Winter (1982) - 0.79; Hagedoorn (1993) - 0.77; Powell et al. } \\
\text { (1996) - 0.74; Lane and Lubatkin (1998) - 0.74; Mowery et al. (1996) - } \\
\text { 0.71; Anand and Khanna (2000) - 0.71; Kale et al. (2002) - 0.67; Kogut and } \\
\text { Zander (1992) - 0.65; Barney (1991) - 0.62; Cohen and Levinthal (1990) - } \\
\text { 0.62; Koza and Lewin (1998) - 0.55; Eisenhardt and Schoonhoven (1996) - } \\
\text { 0.50; Khanna et al. (1998) - 0.49; Hamel (1991) - 0.48 }\end{array}$ \\
\hline & $\begin{array}{l}\text { Governance and } \\
\text { transaction costs }\end{array}$ & $\begin{array}{l}\text { Oxley (1997) - 0.78; Parkhe (1993a) - 0.78; Ring and Van de Ven (1994) - } \\
\text { 0.72; Doz (1998) - 0.72; Hennart (1988) - 0.71; Williamson (1975) - 0.68; } \\
\text { Inkpen and Beamish (1997) - 0.66; Williamson (1985) - 0.64; Williamson } \\
\text { (1991) - 0.61; Kogut (1988) - 0.55; Doz (1996) - 0.51 }\end{array}$ \\
\hline & $\begin{array}{l}\text { Alliance formation and } \\
\text { coordination }\end{array}$ & $\begin{array}{l}\text { Gulati (1995a) - 0.90; Gulati (1998) - 0.88; Gulati (1995b) - 0.87; Gulati } \\
\text { and Singh (1998) - 0.78; Zaheer, Gulati and Nohria (2000) - } 0.67\end{array}$ \\
\hline & Social networks & Dyer and Singh (1998) - 0.69 \\
\hline \multirow{4}{*}{ 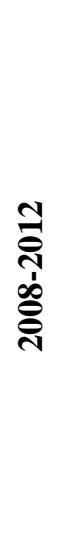 } & $\begin{array}{l}\text { Knowledge transfer and } \\
\text { learning }\end{array}$ & $\begin{array}{l}\text { Grant and Baden-Fuller (2004) - 0.875; March (1991) - 0.859; Kogut and } \\
\text { Zander (1992) - 0.763; Teece et al. (1997) - 0.698; Lane and Lubatkn } \\
\text { (1998) - 0.688; Mowery et al. (1996) - 0.681; Kale et al. }(2000)-0.653 \text {; } \\
\text { Hamel (1991) - 0.603; Barney (1991) - 0.588; Nelson and Winter (1982) - } \\
\text { 0.581; Khanna et al. (1998) - 0.544; Cohen and Levinthal (1990) - 0.418 }\end{array}$ \\
\hline & $\begin{array}{l}\text { Governance and } \\
\text { transaction costs }\end{array}$ & $\begin{array}{l}\text { Parkhe (1993a) - 0.779; Williamson (1975) - 0.741; Doz (1996) - 0.735; } \\
\text { Williamson (1985) - 0.712; Kale et al. (2002) - 0.665; Kogut (1988) - } \\
\text { 0.635; Anand and Khanna (2000) - } 0.626\end{array}$ \\
\hline & Social networks & $\begin{array}{l}\text { Burt (1992) - 0.772; Baum et al. (2000) - 0.745; Ahuja (2000) - 0.673; } \\
\text { Granovetter (1985) - 0.633; Uzzi (1997) - } 0.604\end{array}$ \\
\hline & $\begin{array}{l}\text { Alliance formation and } \\
\text { coordination }\end{array}$ & $\begin{array}{l}\text { Gulati (1995a) - 0.914; Gulati and Singh (1998) - 0.903; Gulati (1998) - } \\
\text { 0.878; Gulati (1995b) - } 0.749\end{array}$ \\
\hline
\end{tabular}

Note: The values are the factor loadings. Source: Authors' computations.

For the first period, years 1993 to 1997, three factors were extracted, with $51 \%$ of the variance explained. For the remaining periods, four factors were extracted, explaining between $60 \%$ and $65 \%$ of the variance. During the first period, the focus on International JVs is clearly an international business/strategy concern to which IB scholars have dedicated much attention (Beamish \& Lupton, 2009). Firms enter JVs to create new products and services, enter new and foreign markets, or both. International JVs (IJVs) enable firms to overcome legal barriers to foreign property restrictions but are also a mean to access the partner to learn, attain economies of scale and scope, develop new products, and avoid making large investments alone. Moreover, using IJVs, firms capture the local partner's help in navigating unfamiliar business environments. However, the choice for IJVs must be compared against alternative entry modes, and given their high failure rates it is important to understand what drives JVs' success (Beamish, 1988; Geringer, 1998; Harrigan, 1985, 1986; Killing, 1983).

The theme Performance and competitive strategy that appears highly connected to IB-related research (1993-97), links alliances and equity forms of interfirm collaboration, because of the attention to outcomes of managers' actions. Performance effects are an important aspect of partnering, including the very rationale for entering into an alliance. Hence, this research involves identifying effects and measures of performance, struggling to find conclusive results due to lack of reliable objective data for empirical tests. The competitive strategy component derives from the choice for collaborating and the impact on firms' long-term strategy. Hamel (1991) specifically noted that international competition between firms denotes asymmetries in firms' skill endowments, and alliances are a means to internalize the skills of others.

Although an extensive analysis of the factors is not possible in this paper, it is worth noting some major shifts (Table 6). For instance, it was in the period 2003-2007 that issues pertaining to learning and 
knowledge became the leading conceptual background for studying strategic alliances. Nonetheless, the stream on learning and knowledge has also changed from focusing on networks and knowledge access to emphasize knowledge transfer - with works on the hazards involved in the transfer, the types of knowledge, and so forth. Nonetheless, much of this research stream still delves into the importance of effectively managing firms' knowledge and capabilities that are conceptualized as the most valuable source of competitive advantage (Beamish \& Lupton, 2009). Recognizing that alliances create value, Anand and Khanna (2000) examined what drives value-creation in alliances, finding evidence of learning effects in managing collaboration.

Table 6

\section{Evolution of Themes Researched}

\begin{tabular}{|c|c|c|c|}
\hline 1993-1997 & 1998-2002 & 2003-2007 & 2008-2012 \\
\hline $\begin{array}{l}\text { 1. Performance and } \\
\text { competitive strategy } \\
\text { 2. International JVs } \\
\text { 3. Governance and } \\
\text { transaction costs }\end{array}$ & $\begin{array}{l}\text { 1. Transaction costs } \\
\text { 2. Learning, networks } \\
\text { and access resources } \\
\text { 3. JVs: Structure and } \\
\text { reciprocity } \\
\text { 4. Interfirm } \\
\text { coordination }\end{array}$ & $\begin{array}{l}\text { 1. Learning and } \\
\text { collaboration } \\
\text { 2. Governance and } \\
\text { transaction costs } \\
\text { 3. Alliance formation } \\
\text { and coordination } \\
\text { 4. Social networks }\end{array}$ & $\begin{array}{l}\text { 1. Knowledge transfer } \\
\text { and learning } \\
\text { 2. Governance and } \\
\text { transaction costs } \\
\text { 3. Social networks } \\
\text { 4. Alliance formation } \\
\text { and coordination }\end{array}$ \\
\hline
\end{tabular}

Moreover, social network-based explanations and a variety of related concepts such as trust between partners emerged more clearly in the period 2003-2007 to become one of the prevailing conceptual foundations of much of the research conducted thereafter. In the last period, 2008-2012, there is a clear decrease in the governance and transaction costs factor that is superseded by knowledge, knowledge transfer, learning and capabilities-based studies.

\section{Co-citation analyses}

Co-citation analyses rely on examining the frequency with which a given pair of works is referenced by other authors. Using the social networks software Ucinet we drew a co-citation network for the entire period. To better read the figure, notice that the thickness of the line connecting a pair of works is a measure of the strength of the tie, as assessed by the co-citation frequency. Hence, the thicker the line connecting a pair the larger the number of co-citations. Also, the works are shown in their relative positions such that more central works are more often cited relative to those in the periphery. All works are placed on a roughly circular space. 
Figure 2 displays the co-citation network for the entire period: 1983-2012. At the center are the works by Hamel (1991), Cohen and Levinthal (1990), Gulati (1995a) and Dyer and Singh (1998). Their relative centrality confirms that these are the most influential works among the 866 in our sample. A second ring is formed by about a dozen works including Mowery et al. (1996), Nelson and Winter (1982), Williamson (1985), Parkhe (1993a), Powell et al. (1996), among others. In the outer ring, at the periphery, are works that albeit relevant for the past twenty years of research are slightly less central. Taken as a whole these are the works that better signal the knowledge in the field.

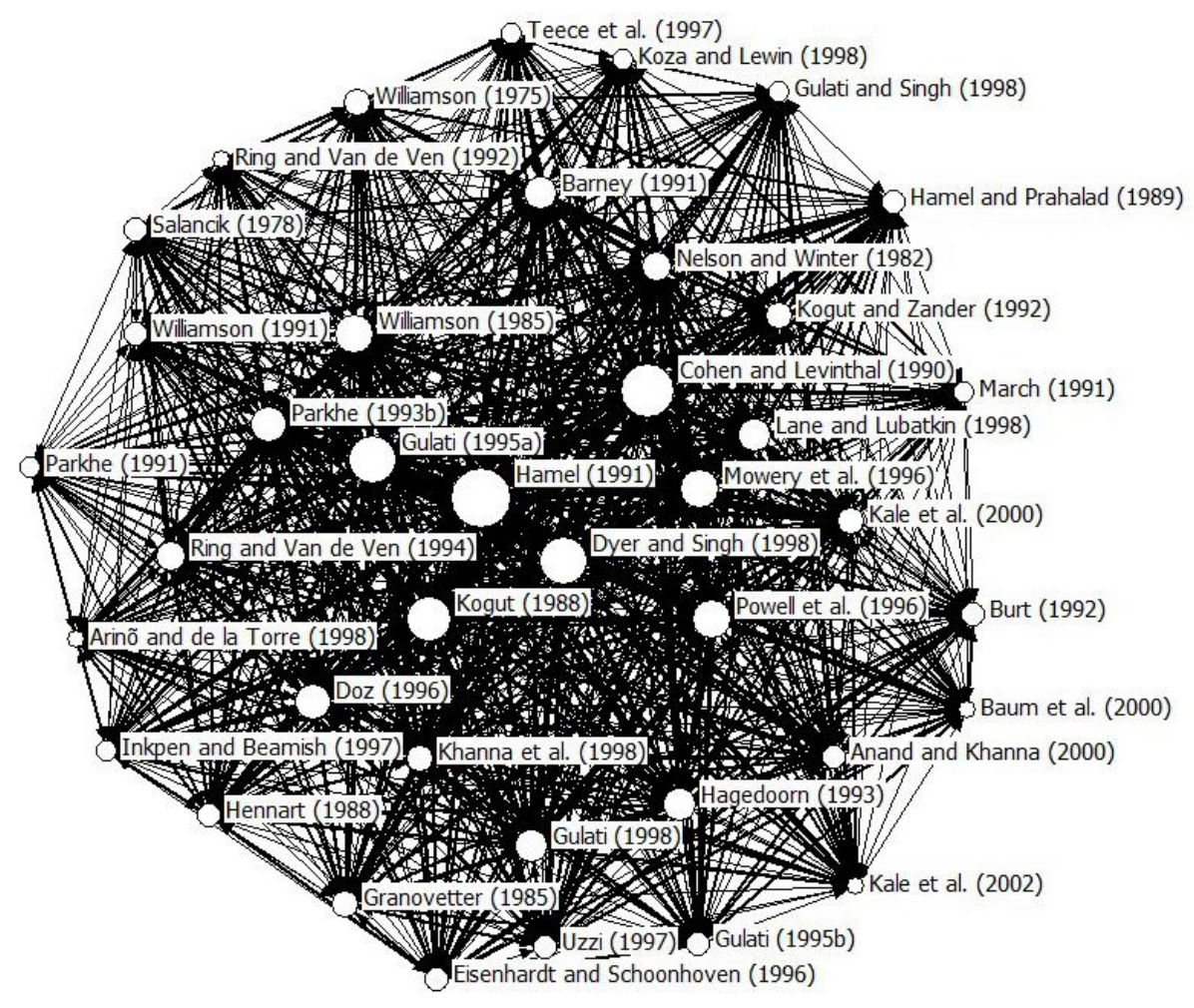

Figure 2. Co-citation Network of the 40 Most Cited Articles: 1983-2012.

Source: Borgatti, S., Everett, M., \& Freeman, L. (2002). Ucinet for Windows: software for social network analysis. Harvard, MA: Analytic Technologies. Persson, O., Danell, R., \& Schneider, J. (2009). How to use Bibexcel for various types of bibliometric analysis. In F. Åström, R. Danell, B. Larsen, \& J. Schneider (Eds.), Celebrating scholarly communication studies: a festschrift for olle persson at his 60th birthday (pp. 9-24). Leuven, Belgium: International Society for Scientometrics and Informetrics.

Additional co-citation analyses for each period (not reproduced here due to space limitations) largely confirm the results of the factor analyses. For instance, during 1993 to 1997, the most central works were Contractor and Lorange (1988), Kogut (1988), Hamel (1991), Killing (1983) and Porter (1986). Taken together these works reflect the study of alliances, and alternative governance models, in an international context. The focus on transaction cost arguments delves into alliances as a hybrid form (Borys \& Jemison, 1989) between the market and the hierarchy (Gulati, 1995a). The tie to firms' competitive strategies is visible in Killing's (1983) and Porter's (1986) work on competition in global industries and how the formation of strategic alliances must be made examining the five forces and the generic strategies - cost leadership, differentiation, and focus - to identify how firms may outperform the competition and overcome uncertainty (Kogut, 1988).

In the period 1998 to 2002 it is the works by Hamel (1991), Gulati (1995a), Kogut (1988) and Doz (1996) at the core of the network. These articles, taken together, denote an emphasis on knowledge access but taking on a transaction-cost approach into the potential hazards involved. Firms have goals, or strategic intents, for the alliances entered into (Hamel, 1991), namely accessing resources held by the partners (Borys \& Jemison, 1989; Kogut, 1988) that are opportunities for organizational learning (Doz, 1996). Firms thus form alliances to, among other reasons, facilitate learning (Hamel, 1991), but need to 
caution for possible opportunistic behaviors of partners. Alliances are thus a manner to minimize total transaction costs.

In the period 2003 to 2007 three works are at the core of the network: Hamel (1991), Cohen and Levinthal (1990) and Dyer and Singh (1998). This is a substantial change over the previous period and marks the emergence of the focus on learning sought in alliances among firms. Hamel (1991) emphasizes how firms are increasingly competing for knowledge-based advantages and form alliances to jointly augment their competences by learning with the partners. Dyer and Singh (1998) also posit that alliances are better seen as cooperative strategies for competitive advantage. Cohen and Levinthal (1990) delve into the hazards involved in learning and the interfirm transfer of knowledge.

Finally, the last period, 2008 to 2012, shows a co-citation network having at the center a set of works focused on the learning dynamics in alliances, such as absorptive capacity (Cohen \& Levinthal, 1990), how firms may learn and yet protect their proprietary assets (Kale, Singh, \& Perlmutter, 2000), learning from partners to achieve a knowledge-based competitive advantage (Hamel, 1991), knowledge transfer in alliances (Mowery, Oxley, \& Silverman, 1996), and the mechanisms for learning (Lane \& Lubatkin, 1998).

\section{Discussion}

In this paper we sought to examine and make sense of the extant research on strategic alliances. We defined top-ranked journals in management, strategy and international business to select a sample of 866 articles that deal specifically with strategic alliances, published in the past twenty years. Methodologically we conducted a bibliometric study based on the well-accepted techniques of citation and co-citation analyses and conducted a factor analysis. The data and results permitted identify the most influential works and their related conceptual approaches, thus better understanding intellectual ties and evolution over time.

This paper complements existing research, both literature reviews and other bibliometric studies. For example, it complements the findings by Lin and Cheng (2010) whose analysis uncovered similar research themes, albeit they failed to perform a longitudinal analysis. It is also a complement to Di Guardo and Harrigan's (2012) bibliometric study, albeit they classified the research themes into network approach, industrial organizational approach, economics of strategy approach, and learning and knowledge transfer approach. It further complements Moran et al.'s (2010) review on strategic alliances. Through a bibliometric analysis, we identified the most influential works on the topic and the intellectual evolution by noting changes in citations over the twenty years considered. Moreover, we traced the evolution of research using a factor analysis, which at least in part permits identifying subfields or intellectual themes. Used together, citation, co-citation and factor analyses help in better understanding the stock of knowledge produced. The core assumption is that research on the topic has matured enough to warrant an examination of the extant literature.

The results, for both the entire period and broken down in 5-year periods, show that strategic alliance research has been built mainly on the back of three theoretical streams: transaction costs, knowledge-based and learning arguments, and social networks. While at the origin the Transaction Cost Theory prevailed, perhaps more notably in international business studies (see Table 5) it has gradually moved to the Resource-Based View and its variants (capability and knowledge-based explanations). The transaction-cost studies concern the governance models adopted by firms, and perhaps more notable was the work by Ranjay Gulati in calling attention to the value of trust in reducing transaction costs, namely those emerging from potential opportunistic behaviors and market uncertainties. Nonetheless, the social structure of the topic, as identified in the co-citation network (Figure 2) and factor analyses (Tables 4 and 5) are clear in showing that learning, knowledge transfer between partners and the development of capabilities has been at the core of much of the research conducted on strategic alliances. This trend has become even clearer in the more recent periods, although we also observe that the two 
latter periods (2003-2007 and 2008-2012) further show a relative increase in the emphasis given to social network arguments and the importance of firms' social embeddedness in networks of alliances. Through alliance ties firms may access not only an array of physical, financial and informational resources, but also social resources such as reputation.

The data and results further denote that the most-cited papers vary over the period which is prima facie evidence of the conceptual shifts taking place. Research on the topic of alliances has thus evolved from a somewhat phenomenon-oriented focus, and mostly in an international business context - where performance effects and the contrast between equity and non-equity based collaborative governance models prevailed - to a topic well-embedded in theoretical lenses. Moreover, we also noted how within the stream of research on learning and knowledge has been changing over time and seems to more recently focus on the actual learning that may occur. Moreover, it is salient that scholars have been able to bring in concepts from other disciplines, perhaps more from sociology, contrasting with the topic's original roots founded in economic and market-power based explanations of why firms seek to form alliances and the potential benefits. In any instance, the main theoretical approaches have not changed markedly and alliance research has been constructed using transaction-cost, resource, knowledge and capabilities-based views and social network concepts. Perhaps more surprising is the relative stability in the citation patterns. Specifically, older papers tend to accumulate a larger number of citations, older papers seem to be the most cited and only a handful of more recent papers reach the top of the most cited.

\section{Limitations and future research avenues}

This study has some limitations worth reviewing. The first concerns our choice of keywords, that while capturing at least most of the research on the topic, may leave out some articles. Perhaps more significant is that even though we used a large pool of journals to draw our sample from (thirty-one journals) these do not cover the entire range of published research. Nonetheless, our selection of only top-ranked journals probably captures the most influential articles and leaves us confident that we captured the most significant papers, but future research may enlarge even more the sample examined and delve into the papers published in such disciplines as finance and human resources.

Other limitations are specific to the bibliometric techniques employed. For instance, we counted citations and co-citations but we fail to uncover the context in which these are made. That is, we are unaware of the purpose of the citations and an author may cite another work to build upon it or to criticize its approach or methods. Future research may seek to use specific content analysis software to uncover the content of the papers and the context in which citations are made.

We also have the limitation of using only articles published. Bibliometric studies may be based on an array of written documentations beyond papers published in scientific journals such as books, dissertations and theses, reports, news in the media, and so forth. By using on articles published we are using what has been termed as certified knowledge since these documents went through a peer review process. Although the review process may not be a perfect system (Bedeian, 2004; Frey, 2003), it is a reliable procedure for the advancement of scientific knowledge (Shugan, 2007). Notwithstanding, future research may extend our analyses to other source documents and perhaps find empirical relationships and conceptual ideas that have not made it to mainstream top management journals.

Research on strategic alliances has been fairly absent from Brazilian scholars' attention. It seems reasonable to note that much of the national research has focused on theoretical approaches, such as Eiriz (2001) on the typologies of strategic alliances, and examining the learning and interorganizational learning potential of alliances (Klotzle, 2002; Mozzato \& Bitencourt, 2014). However, there is a wide array of theoretical perspectives to further explore, that may also find an empirical context with Brazilian firms. For instance, discussing internationalization, how do firms decide on partner selection and how do they assess governance and transaction costs that may be involved? How do Brazilian multinationals coordinate their portfolio of alliances? In fact, what the motivations underlying internationalization are and whether these are better attained using alliances or acquisitions, for instance, is still unclear. The 
field of international business, in specific, may find that studying alliance selection, formation and coordination is a munificent arena with practical implications for multinationals' strategies.

Perhaps in developing future research it is useful to build on the existing stock of knowledge that we identified. This also means that an initial set of bibliography probably needs to comprise the most influential works (see Table 2 and Figure 2). Testing the theories in an emerging economy context, with the institutional inefficiencies and voids that are well known (Cuervo-Cazurra \& Genc, 2008), is likely to uncover novel insights with theory development potential. For example, the literature emphasized the role of trust (Gulati, 1995a, 1995b) on alliance formation, but it is reasonable to suggest that trust is especially relevant when formal institutions fail. The social, cultural, economic and institutional environment that characterizes countries and interfirm interactions are likely to impact on not only how alliances are formed and managed, but also on their longevity.

\section{Concluding Remarks}

Bibliometric studies provide a quantitative analysis of the past research on a given discipline or topic, and are a good complement to other types of literature review. Using the data and results of studies based on bibliometric techniques, experienced scholars may identify opportunities for future research in the field, while newcomers, young scholars, and doctoral students may use these studies to better understand the scope of the field, its seminal works, main trends, evolutions, theories, context and prevailing paradigms.

Bibliometric studies do not provide an account for the state of the art of knowledge on a topic but rather they examine the knowledge that has accumulated. In this study we identified the most influential works, examined the intellectual ties binding works, and scrutinized the theoretical evolution of research on strategic alliances over the past twenty years. To some extent our findings corroborate RamosRodríguez and Ruíz-Navarro (2004) and Shafique's (2013) observation of the increasing importance of resource-based explanations, including knowledge and capabilities. We also found that the social interactions, as examined in social network literature, is prominent when studying interfirm collaborations. Moreover, while the most influential works have been to some extent classic or seminal pieces, there is an emergence of scholars that bring to the forefront of research novel approaches to study strategic alliances. Future studies on the topic will reveal whether the structures we identified are enduring or more driven by specifics that have marked much of the management research during the past decades or whether insightful avenues will emerge to broaden scholars and practitioners' views on strategic alliances.

\section{References}

Acedo, F. J., Barroso, C., \& Galan, J. L. (2006). The resource-based theory: dissemination and main trends. Strategic Management Journal, 27(7), 621-636. doi: 10.1002/smj.532

Anand, B. N., \& Khanna, T. (2000). Do firms learn to create value? The case of alliances. Strategic Management Journal, 21(3), 295-315. doi: 10.1002/(SICI)1097-0266(200003)21:3<295::AIDSMJ91>3.0.CO;2-O

Ahuja, G. (2000). Collaboration networks, structural holes, and innovation: a longitudinal study. Administrative Science Quarterly, 45(3), 425-455. doi: 10.2307/2667105

Ariño, A., \& Torre, J. de la (1998). Learning from failure: towards and evolutionary model of collaborative ventures. Organization Science, 9(3), 306-325. doi: 10.1287/orsc.9.3.306 
Axelrod, R. (1984). The evolution of cooperation. New York, NY: Basic Books.

Barkema, H. G., \& Vermeulen, F. (1998). International expansion through start-up or acquisition: a learning perspective. Academy of Management Journal, 41(1), 7-23.

Barney, J. (1991). Firm resources and sustained competitive advantage. Journal of Management, 17(1), 99-120. doi: 10.1177/014920639101700108

Baum, J. A. C., Calabrese, T., \& Silverman, B. S. (2000). Don't go it alone: alliance network composition and startups' performance in Canadian biotechnology. Strategic Management Journal, 21(3), 267294. doi: 10.1002/(SICI)1097-0266(200003)21:3<267::AID-SMJ89>3.0.CO;2-8

Beamish, P. (1988). Multinational joint ventures in developing countries. New York: Routledge.

Beamish, P., \& Lupton, N. (2009). Managing joint ventures. Academy of Management Perspectives, 23(2), 75-94, 2009.

Bedeian, A. G. (2004). Peer review and the social construction of knowledge in the management discipline. Academy of Management Learning \& Education, 3(2), 198-216.

Borgatti, S., Everett, M., \& Freeman, L. (2002). Ucinet for Windows: software for social network analysis. Harvard, MA: Analytic Technologies.

Borys, B., \& Jemison, D. B. (1989). Hybrid arrangements as strategic alliances: theoretical issues in organizational combinations. Academy of Management Review, 14(2), 234-249. doi: $10.2307 / 258418$

Broadus, R. N. (1987). Towards a definition of "bibliometrics". Scientometrics, 12(5-6), 373-379. doi: 10.1007/BF02016680

Buckley, P., \& Casson, M. (1988). A theory of cooperation in international business. In F. Contractor \& P. Lorange (Eds.), Cooperative strategies in international business (pp. 31-53). Lexington, MA: Lexington Books.

Burt, R. (1992). Structural holes: the social structure of competition. Cambridge, MA: Harvard University Press.

Cohen, W., \& Levinthal, D. (1990). Absorptive capacity: a new perspective on learning and innovation. Administrative Science Quarterly, 35(1), 128-152.

Contractor, F., \& Lorange, P. (1988). Why should firms cooperate? The strategy and economics basis for cooperative ventures. In F. Contractor \& P. Lorange (Eds.), Cooperative strategies in international business (pp. 3-28). Lexington, MA: Lexington Books.

Cuervo-Cazurra, A., \& Genc, M. (2008). Transforming disadvantages into advantages: developingcountry MNEs in the least developed countries. Journal of International Business Studies, 39(6), 957-979. doi: 10.1057/palgrave.jibs.8400390

Culnan, M. J., O'Reilly, C. A., III, \& Chatman, J. A. (1990). Intellectual structure of research in organizational behavior, 1972-1984: a co-citation analysis. Journal of the American Society for Information Science, 41(6), 453-458. doi: 10.1002/(SICI)1097-4571(199009)41:6<453::AIDASI13>3.0.CO;2-E

Das, T., \& Teng, B-S. (1998). Between trust and control: developing confidence in partner cooperation in alliances. Academy of Management Review, 23(3), 491-512. doi: 10.5465/AMR.1998.926623

Day, G. S. (1995). Advantageous alliances. Journal of the Academy of Marketing Science, 23(4), 297300. doi: $10.1177 / 009207039502300409$ 
Di Guardo, M. C., \& Harrigan, K. R. (2012). Mapping research on strategic alliances and innovation: a co-citation analysis. The Journal of Technology Transfer, 37(6), 789-811. doi: 10.1007/s10961011-9239-2

Doz, Y. L. (1996). The evolution of cooperation in strategic alliances: initial conditions or learning processes?. Strategic Management Journal, 17(SI), 55-83. doi: 10.1002/smj.4250171006

Doz, Y. L. (1998). Alliance advantage: the art of creating value through partnering. Cambridge, MA: Harvard Business Press.

Doz, Y. L., Olk, P. M., \& Ring, P. S. (2000). Formation processes of R\&D consortia: Which path to take? Where does it lead? Strategic Management Journal, 21(3), 239-266. doi: 10.1002/(SICI)1097-0266(200003)21:3<239::AID-SMJ97>3.0.CO;2-K

Dyer, J. H., \& Singh, H. (1998). The relational view: cooperative strategy and sources of interorganizational competitive advantage. Academy of Management Review, 23(4), 660-679. doi: 10.5465/AMR.1998.1255632

Eiriz, V. (2001). Proposta de tipologia sobre alianças estratégicas. Revista de Administração Contemporânea, 5(2), 65-90. doi: 10.1590/S1415-65552001000200004

Eisenhardt, K. M., \& Schoonhoven, C. B. (1996). Resource-based view of strategic alliance formation: strategic and social effects in entrepreneurial firms. Organization Science, 7(2), 136-150. doi: 10.1287/orsc.7.2.136

Fabrigar, L. R., Wegener, D. T., MacCallum, R. C., \& Strahan, E. J. (1999). Evaluating the use of exploratory factor analysis in psychological research. Psychological Methods, 4(3), 272-299. doi: 10.1037/1082-989X.4.3.272

Ferreira, M. (2011). A bibliometric study on Ghoshal's managing across borders. Multinational Business Review, 19(4), 357-375.

Frey, B. S. (2003). Publishing as prostitution? Choosing between one's own ideas and academic success. Public Choice, 116(1-2), 205-223. doi: 10.1023/A:1024208701874

Furrer, O., Tomas, H., \& Goussevskaia, A. (2008). The structure and evolution of the strategic management field: a content analysis of 26 years of strategic management research. International Journal of Management Reviews, 10(1), 1-23. doi: 10.1111/j.1468-2370.2007.00217.x

Geringer, J. M. (1991). Strategic determinants of partner selection criteria in international joint ventures. Journal of International Business Studies, 22(1), 41-62. doi: 10.1057/palgrave.jibs.8490291

Geringer, J. M. (1998). Joint venture partner selection: strategies for developed countries. New York, NY: Quorum Books.

Geringer, J. M., \& Hebert, L. (1989). Control and performance of international ventures. Journal of International Business Studies, 20(2), 235-254.

Granovetter, M. (1985). Economic action and social structure: the problem of embeddedness. American Journal of Sociology, 91(3), 481-510.

Grant, R. M., \& Baden-Fuller, C. (2004). A knowledge accessing theory of strategic alliances. Journal of Management Studies, 41(1), 61-84. doi: 10.1111/j.1467-6486.2004.00421.x

Gulati, R. (1995a). Does familiarity breed trust? The implications of repeated ties for contractual choice in alliances. Academy of Management Journal, 38(1), 85-112. doi: 10.2307/256729 
Gulati, R. (1995b). Social structure and alliance formation patterns: a longitudinal analysis. Administrative Science Quarterly, 40(4), 619-652.

Gulati, R. (1998). Alliances and networks. Strategic Management Journal, 19(4), 293-317. doi: 10.1002/(SICI)1097-0266(199804)19:4<293::AID-SMJ982>3.0.CO;2-M

Gulati, R., \& Singh, H. (1998). The architecture of cooperation: managing coordination costs and appropriation concerns in strategic alliances. Administrative Science Quarterly, 43(4), 781-814.

Hladik, K. (1985). International joint ventures: an empirical investigation into the characteristics of recent US-foreign joint venture partnerships. Lexington, MA: Lexington Books.

Hagedoorn, J. (1993). Understanding the rationale of strategic technology partnering: interorganizational modes of cooperation and sectoral differences. Strategic Management Journal, 14(5), 371-385. doi: 10.1002/smj.4250140505

Hamel, G. (1991). Competition for competence and interpartner learning within international strategic alliances. Strategic Management Journal, 12(1), 83-103. doi: 10.1002/smj.4250120908

Hamel, G., Doz, Y. L., \& Prahalad, C. K. (1989). Collaborate with your competitors and win. Harvard Business Review, 67(1), 133-134.

Hamel, G., \& Prahalad, C. (1989). To revitalize corporate performance, we need a whole new model of strategy. Harvard Business Review, 67(3), 63-76.

Harrigan, K. (1985). Strategies for joint ventures. Lexington, MA: Lexington Books.

Harrigan, K. (1986). Managing for joint venture success. Lexington, MA: Lexington Books.

Harrigan, K. (1988). Joint ventures and competitive strategy. Strategic Management Journal, 9(2), 141158. doi: $10.1002 / \mathrm{smj} .4250090205$

Harzing, A-W. (2002). Acquisitions versus greenfield investments: international strategy and management of entry modes. Strategic Management Journal, 23(3), 211-227. doi: $10.1002 / \mathrm{smj} .218$

Harzing, A-W. (2014, February 11). Journal quality list (52th ed., pp. 1-36). Retrieved from http://www.harzing.com/download/jql_subject.pdf

Hennart, J.-R. (1988). A transaction costs theory of equity joint ventures. Strategic Management Journal, 9(4), 361-374. doi: 10.1002/smj.4250090406

Inkpen, A. C., \& Beamish, P. W. (1997). Knowledge, bargaining power, and the instability of international joint ventures. Academy of Management Review, 22(1), 177-202. doi: 10.5465/AMR.1997.9707180263

Kale, P., Dyer, J., \& Singh, H. (2002). Alliance capability, stock market response, and long-term alliance success: the role of the alliance function. Strategic Management Journal, 23(8), 747-767. doi: $10.1002 / \mathrm{smj} .248$

Kale, P., Singh, H., \& Perlmutter, H. (2000). Learning and protection of proprietary assets in strategic alliances: building relational capital. Strategic Management Journal, 21(3), 217-237. doi: 10.1002/(SICI)1097-0266(200003)21:3<217::AID-SMJ95>3.0.CO;2-Y

Khanna, T., Gulati, R., \& Nohria, N. (1998). The dynamics of learning alliances: competition, cooperation, and relative scope. Strategic Management Journal, 19(3), 193-210. doi: 10.1002/(SICI)1097-0266(199803)19:3<193::AID-SMJ949>3.0.CO;2-C

Killing, J. (1983). Strategies for joint venture success. New York, NY: Praeger. 
Killing, J. (1988). Understanding alliances: the role of task and organizational complexity. In F. Contractor \& P. Lorange (Eds.), Cooperative strategies in international business (pp. 55-67). Lexington, MA: Lexington Books.

Klotzle, M. K. (2002). Alianças estratégicas: conceito e teoria. Revista de Administração Contemporânea, 6(1), 85-104. doi: 10.1590/S1415-65552002000100006

Kogut, B. (1988). Joint ventures: theoretical and empirical perspectives. Strategic Management Journal, 9(4), 319-332. doi: 10.1002/smj.4250090403

Kogut, B. (1989). The stability of joint ventures: reciprocity and competitive rivalry. The Journal of Industrial Economics, 38(2), 183-198. doi: 10.2307/2098529

Kogut, B., \& Zander, U. (1992). Knowledge of the firm, combinative capabilities, and the replication of technology. Organization Science, 3(3), 383-397. doi: 10.1287/orsc.3.3.383

Koza, M. P., \& Lewin, A. Y. (1998). The co-evolution of strategic alliances. Organization Science, 9(3), 255-264. doi: 10.1287/orsc.9.3.255

Lane, P. J., \& Lubatkin, M. (1998). Relative absorptive capacity and interorganizational learning. Strategic Management Journal, 19(5), 461-477. doi: 10.1002/(SICI)10970266(199805)19:5<461::AID-SMJ953>3.0.CO;2-L

Leydesdorff, L. (1987). Various methods for the mapping of science. Scientometrics, 11(5), 295-324. doi: 10.1007/BF02279351

Li, D., \& Ferreira, M. P. (2008). Partner selection for international strategic alliances in emerging economies. Scandinavian Journal of Management, 24(4), 308-319. doi: 10.1016/j.scaman.2008.05.001

Lin, T., \& Cheng, Y. (2010). Exploring the knowledge network of strategic alliance research: a cocitation analysis. International Journal of Electronic Business Management, 8(2), 152-160.

March, J. G. (1991). Exploration and exploitation in organizational learning. Organization Science, 2(1), 71-87. doi: 10.1287/orsc.2.1.71

McCain, K. W. (1986). Cocited author mapping as a valid representation of intellectual structure. Journal of the American Society for Information Science, 37(3), 111-122. doi: 10.1002/(SICI)1097-4571(198605)37:3<111::AID-ASI2>3.0.CO;2-D

McCain, K. W. (1990). Mapping authors in intellectual space: a technical overview. Journal of the American Society for Information Science, 41(6), 433-443. doi: 10.1002/(SICI)10974571(199009)41:6<433::AID-ASI11>3.0.CO;2-Q

McCain, K. W. (1991). Mapping economics through the journal literature: an experiment in journal cocitation. Journal of the American Society for Information Science, 42(4), 290-296. doi: 10.1002/(SICI)1097-4571(199105)42:4<290::AID-ASI5>3.0.CO;2-9

Moran, M. R., Souza, F. F. de, Boaventura, J. M. G., Marinho, B. L. de, \& Fischmann, A. A. (2010). Alianças estratégicas: uma análise bibliométrica da produção científica entre 1989 e 2008. Revista de Ciências da Administração, 12(27), 42-62. doi: 10.5007/2175-8077.2010v12n27p63

Mowery, D. C., Oxley, J. E., \& Silverman, B. (1996). Strategic alliances and interfirm knowledge transfer. Strategic Management Journal, 17(S2), 77-91. doi: 10.1002/smj.4250171108

Mozzato, A. R., \& Bitencourt, C. C. (2014). Understanding interorganizational learning based on social spaces and learning episodes. Brazilian Administration Review, 11(3), 284-301. Retrieved from 
http://www.scielo.br/pdf/bar/v11n3/1807-7692-bar-11-3-0284.pdf. doi: 10.1590/18077692 bar2014370

Nelson, R., \& Winter, S. (1982). An evolutionary theory of economic change. Cambridge, MA: Harvard University Press.

Nerur, S. P., Rasheed, A. A., \& Natarajan, V. (2008). The intellectual structure of the strategic management field: an author co-citation analysis. Strategic Management Journal, 29(3), 319-336. doi: $10.1002 / \mathrm{smj} .659$

Osborn, R. N., \& Baughn, C. C. (1990). Forms of interorganizational governance for multinational alliances. Academy of Management Journal, 33(3), 503-519. doi: 10.2307/256578

Oxley, J. (1997). Appropriability hazards and governance in strategic alliances: a transaction cost approach. Journal of law, Economics, and Organization, 13(2), 387-409.

Park, S. H., \& Ungson, G. R. (1997). The effect of national culture, organizational complementarity, and economic motivation on joint venture dissolution. Academy of Management Journal, 40(2), 279-307. doi: $10.2307 / 256884$

Parkhe, A. (1991). Interfirm diversity, organizational learning, and longevity in global strategic alliances. Journal of International Business Studies, 22(4), 579-601. doi: 10.1057/palgrave.jibs. 8490315

Parkhe, A. (1993a). Strategic alliance structuring: a game theoretic and transaction cost examination of interfirm cooperation. Academy of Management Journal, 36(4), 794-829. doi: 10.2307/256759

Parkhe, A. (1993b). "Messy" research, methodological predispositions, and theory development in international joint ventures. Academy of Management Review, 18(2), 227-268.

Persson, O., Danell, R., \& Schneider, J. (2009). How to use Bibexcel for various types of bibliometric analysis. In F. Àström, R. Danell, B. Larsen, \& J. Schneider (Eds.), Celebrating scholarly communication studies: a festschrift for olle persson at his 60th birthday (pp. 9-24). Leuven, Belgium: International Society for Scientometrics and Informetrics.

Pfeffer, J., \& Salancik, G. (1978). The external control of organizations: a resource perspective. New York: Harper \& Row.

Phelan, S. E., Ferreira, M. P., \& Salvador, R. (2002). The first twenty years of the Strategic Management Journal. Strategic Management Journal, 23(12), 1161-1168. doi: 10.1002/smj.268

Porter, M. (1980). Competitive strategy. New York, NY: The Free Press.

Porter, M. (1985). Competitive advantage. New York, NY: The Free Press.

Porter, M. (1986). Competition in global industries. Boston, MA: Harvard Business Press.

Porter, M. (1990). Competitive advantage of nations. New York, NY: The Free Press.

Powell, W. W. (1990). Neither market nor hierarchy: network forms of organization. Research in Organizational Behavior, 12, 295-336.

Powell, W. W., Koput, K. W., \& Smith-Doerr, L. (1996). Interorganizational collaboration and the locus of innovation: networks of learning in biotechnology. Administrative Science Quarterly, 41(1), 116-145. doi: $10.2307 / 2393988$

Pritchard, A. (1969). Statistical bibliography or bibliometrics? Journal of Documentation, 25(4), 348349. 
Ramos-Rodríguez, A.-R., \& Ruíz-Navarro, J. (2004). Changes in the intellectual structure of strategic management research: a bibliometric study of the Strategic Management Journal, 1980-2000. Strategic Management Journal, 25(10), 981-1004. doi: 10.1002/smj.397

Reich, R., \& Mankin, E. (1986). Joint ventures with Japan give away America's future. Harvard Business Review, 136-152.

Ring, P., \& Van de Ven, A. (1992). Structuring cooperative relationships between organizations. Strategic Management Journal, 13(7), 483-498. doi: 10.1002/smj.4250130702

Ring, P. S., \& Van de Ven, A. H. (1994). Developmental processes of cooperative interorganizational relationships. Academy of Management Review, 19(1), 90-118.

Schildt, H. A., Zahra, S. A., \& Silanpää, A. (2006). Scholarly communities in entrepreneurship research: a co-citation analysis. Entrepreneurship Theory \& Practice, 30(3), 399-415. doi: 10.1111/j.15406520.2006.00126.x

Shafique, M. (2013). Thinking inside the box? Intellectual structure of the knowledge base of innovation research (1988-2008). Strategic Management Journal, 34(1), 62-93. doi: 10.1002/smj.2002

Shah, R. H., \& Swaminathan, V. (2008). Factors influencing partner selection in strategic alliances: the moderating role of alliance context. Strategic Management Journal, 29(5), 471-494. doi: 10.1002/smj.656

Shane, S. (1997). Who is publishing the entrepreneurship research?, Journal of Management, 23(1), 8395. doi: $10.1177 / 014920639702300105$

Shugan, S. M. (2007). The editor's secrets. Marketing Science, 26(5), 589-595. doi $10.1287 / \mathrm{mksc} .1070 .0309$

Small, H. (1973). Co-citation in the scientific literature: a new measure of the relationship between two documents. Journal of the American Society for information Science, 24(4), 265-269. doi: 10.1002/asi.4630240406

Small, H., \& Garfield, E. (1993). Co-citation analysis of science: henry small on mapping the collective mind of science. Current Comments, (19), 3-13.

Subramanyam, K. (1983). Bibliometric studies of research collaboration: a review. Journal of Information Science, 6(1), 33-38. doi: 10.1177/016555158300600105

Teece, D. J., Pisano, G., \& Shuen, A. (1997). Dynamic capabilities and strategic management. Strategic Management Journal, 18(7), 509-533. doi: 10.1002/(SICI)1097-0266(199708)18:7<509::AIDSMJ882>3.0.CO;2-Z

Uzzi, B. (1997). Social structure and competition in interfirm networks: the paradox of embeddedness. Administrative Science Quarterly, 42(1), 35-67. doi: 10.2307/2393808

Varadarajan, P. R., \& Cunningham, M. H. (1995). Strategic alliances: a synthesis of conceptual foundations. Journal of the Academy of Marketing Science, 23(4), 282-296. doi: $10.1177 / 009207039502300408$

Vermeulen, F., \& Barkema, H. (2001). Learning through acquisitions. Academy of Management Journal, 44(3), 457-476. doi: 10.2307/3069364

Web of Science. (n.d.). Faça login para acessar o Web of Science. Recuperado de http://apps.webofknowledge.com/WOS_GeneralSearch_input.do?product=WOS\&SID=Q2VSs C8ChkihDbZkvFR\&search_mode=GeneralSearch 
White, H. D., \& McCain, K. W. (1998). Visualizing a discipline: an author co-citation analysis of information science, 1972-1995. Journal of the American Society for Information Science, 49(4), 327-355. doi: 10.1002/(SICI)1097-4571(19980401)49:4<327::AID-ASI4>3.0.CO;2-4

Williamson, O. E. (1975). Markets and hierarchies, analysis and antitrust implications: a study in the economics of internal organization. New York, NY: The Free Press.

Williamson, O. E. (1985). The economic institutions of capitalism: firms, markets, relational contracting. New York, NY: The Free Press.

Williamson, O. E. (1991). Comparative economic organization: the analysis of discrete structural alternatives. Administrative Science Quarterly, 36(2), 269-296. doi: 10.2307/2393356

Yan, A., \& Gray, B. (1994). Bargaining power, management control, and performance in United StatesChina joint ventures: a comparative case study. Academy of Management Journal, 37(6), 14781517.

Zaheer, A., Gulati, R., \& Nohria, N. (2000). Strategic networks. Strategic Management Journal, 21(3), 203-215. doi: 10.1002/(SICI)1097-0266(200003)21:3<203::AID-SMJ102>3.0.CO;2-K 